\title{
Characteristics Differences Of Athlete Blood Pressure Of Sports Pre Nasional Sport Event In West Kalimantan
}

\author{
Isti Dwi Puspita Wati' ${ }^{1)}$, Victor G. Simanjuntak ${ }^{2)}$ \\ Program Studi Pendidikan Kepelatihan Olahraga \\ Program Studi Pendidikan Jasmani \\ Fakultas Keguruan dan Ilmu Pendidikan \\ ${ }^{1,2}$ Universitas Tanjungpura, Kalimantan Barat Indonesia \\ Email: ${ }^{1}$ isti.dwi.puspita.w@ fkip.untan.ac.id, ${ }^{2}$ victorgsm@yahoo.com
}

\begin{abstract}
Blood pressure is an indicator of a person's health. Athletes should be have normal blood pressure levels. Exercise provides health benefits, one which is the prevention of hypertension. Exercise conditions and levels of physical and psychological stress put pressure on athletes so that is likely to affect blood pressure. High training intensity based on reviews has a positive impact on high blood pressure so that becomes normal. The purpose this study was to describe the characteristics of an athlete's blood pressure in anaerobic sports. The research method used research is survey research. This type of research is descriptive. The population in this study Pre-PON 2019 athletes in West Kalimantan, while the sample used was athletes in the anaerobic sports group. Anaerobic athletes are assumed to be a definite high-intensity exercise. The sampling technique in this study was purposive sampling. The results showed that from 10 anaerobic sports, 46 athletes were included in criteria for normal blood pressure, while 128 other athletes were included in criteria for prehypertension and hypertension. The conclusion of this study is athletes who experience prehypertension and hypertension will have an impact on health and will interfere with the athlete's performance.
\end{abstract}

Keywords: Blood Pressure, Anaerobic, Hypertension

\section{Perbedaan Karakteristik Cabang Olahraga Dengan Tekanan Darah Atlet Prapon Kalimantan Barat ABSTRAK}

Tekanan darah menjadi salah satu indikator kesehatan seseorang. Atlet semestinya memilki level tekanan darah yang normal. Olahraga memberikan keuntungan terhadap kesehatan, salah satunya pencegahan terjadinya hipertensi. Kondisi latihan dan tingkat stress fisik dan psikologis memberikan tekanan kepada atlet sehingga kemungkinan akan berpengaruh kepada tekanan darah Intensitas latihan yang tinggi berdasarkan review memberikan dampak yang positif terhadap tekanan darah tinggi sehingga menjadi normal. Tujuan penelitian ini adalah untuk menggambarkan karakteristik tekanan darah atlet pada cabang olahraga anaerobic. Metode penelitian yang digunakan dalam penelitian ini adalah penelitian survey. Jenis penelitian ini yaitu deskriptif. Adapun populasi pada penelitian ini adalah atlet Pra PON 2019 di Kalimantan Barat, sedangkan sampel yang digunakan adalah atlet pada kelompok cabang olahraga anaerobic. Atlet cabang olahraga anaerobic diasumsikan latihan pasti berintensitas tinggi. Teknik pengambilan sampel pada penelitian ini adalah purposive sampling. Hasil penelitian diketahui bahwa dari 10 cabang olahraga anaerobik terdapat 46 atlet yang termasuk dalam kriteria tekanan darah normal, sedangkan 128 atlet yang lain termasuk dalam kriteria prehipertensi dan hipertensi. Kesimpulan dari penelitian ini adalah atlet yang mengalami prehipertensi dan hipertensi akan berdampak pada kesehatan dan akan mengganggu perfoma atlet.

Kata Kunci: Tekanan darah, Anaerobik, Hipertensi

(C) 2020 IKIP BUDI UTOMO MALANG

Info Artikel

P-ISSN 2613-9421

Dikirim : 30 September 2020

E-ISSN 2654-8003

Diterima : 19 Oktober 2020

Dipublikasikan : 12 November 2020

Alamat korespondensi: isti.dwi.puspita.w@fkip.untan.ac.id

Universitas Tanjungpura, Jl. Prof. Dr. H. Hadari Nawawi, Bansir Laut, Kec. Pontianak Tenggara, Kota Pontianak,

Kalimantan Barat, 78124 Indonesia 


\section{PENDAHULUAN}

Gerak merupakan kebutuhan mendasar manusia untuk dapat bertahan. Gerak manusia itu dapat dikategorikan menjadi dua kriteria, yaitu terukur dan tidak terukur. Gerak yang tidak terukur disebut juga dengan aktivitas fisik, sedangkan yang terukur disebut dengan olahraga. Aktivitas fisik merupakan aktivitas gerak sehari-hari yang melibatkan fisik manusia. Sedangkan olahraga lebih mengacu pada keadaan manusia untuk melakukan aktivitas fisik yang terencana, terukur dan kontinyu Oleh karena itu olahraga akan memberikan dampak yang positif terhadap kesehatan. Olahraga memiliki banyak manfaat, selain untuk mendapatkan kebanggaan karena memperoleh prestasi maka fungsi lainnya adalah untuk menjaga kesehatan bagi para pelakunya. Peningkatan tingkat kesehatan dapat terjadi ketika olahraga dilakukan secara kontinyu, teratur dan terukur

Olahraga memberikan keuntungan untuk kesehatan jantung paru. Frekuensi dari olahraga dihubungkan dengan penurunan kematian akibat penyakit kardiovaskuler (Nystoriak \& Bhatnagar, 2018) . Orang yang aktif berolahraga akan menurunkan tekanan darah, sensitifitas insulin yang tinggi dan keadaan plasma lipoprotein. Respons tekanan darah yang berlebihan terhadap olahraga dapat meningkatkan risiko kejadian hipertensi pada atlet yang sangat terlatih dan normotensi selama periode jangka menengah (Caselli et al., 2019). Bahkan olahraga menjadi salah satu alternatif dalam menangani gegar otak (Leddy et al., 2018)

Berdasarkan 3 penelitian tersebut dapat diketahui bahwa olahraga yang teratur akan memiliki banyak dampak positif, terutama pada tekanan darah baik itu systole maupun diastole. Selain itu, perbedaan jenis karakteristik gerak dari olahraga akan menyebabkan hasil tekanan darah yang berbeda. Semakin tinggi intensitas latihan yang dilakukan maka akan memberikan dampak penurunan tekanan diastolic. Selama olahraga jantung mengalami tekanan untuk memberikan suplai darah bagi tubuh. Semakin tinggi olahraga maka akan semakin tinggi pula tekanan jantung. Untuk itu jantung akan beradaptasi secara morfologis untuk meningkatkan massa terutama meningkatkan ventrikel dinding jantung. 
Latihan fisik dapat membantu dalam memperbaiki situasi tekanan darah pada pasien gagal ginjal dan secara signifikan mengurangi $\mathrm{VO}_{2}$ pada pasien gagal ginjal (Qiu et al., 2017). Program latihan berisi pemanasan, kekuatan, dan senam aerobik memiliki manfaat dalam tekanan darah pada orang yang sakit dan meningkatkan tingkat konsumsi oksigen yang maksimal.

HIIT menyebabkan penurunan tekanan darah diastolik malam hari yang lebih baik dibandingkan dengan MICT. Selain itu, penurunan tekanan darah siang hari yang hampir signifikan ditemukan dengan HIIT dibandingkan dengan MICT (Way et al., 2019). Berdasarkan penelitian Way dkk mengindikasikan bahwa perbedaan intensitas akan membuat perbedaan tekanan darah.

Perbedaan intensitas akan membuat perbedaan sistem energi yang dilibatkan oleh tubuh untuk bekerja. Selama olahraga, tubuh akan mengeluarkan tiga sistem energi yaitu sistem anaerobic alaktik, sistem anaerobik dan sistem aerobik. Perbedaan penggunaan sistem energi yang dipakai tergantung dari intensitas olahraga yang dilakukan. Atlet yang berkompetisi dalam olahraga yang membutuhkan akselerasi durasi pendek menggunakan sistem a-laktik anaerobic. Sistem a-laktik anaerobic tidak menciptakan energi untuk durasi yang cukup untuk menghasilkan banyak produk limbah yang disebut dengan asam laktat.

Sistem laktik anaerobik (AL) (juga dikenal sebagai glikolisis cepat) menyediakan energi untuk aktivitas intensitas sedang hingga tinggi yang berlangsung dari sepuluh detik hingga dua menit. Sistem laktik anaerobik, serta sistem ATP-CP, mampu mencapai tingkat intensitas tinggi, dan tidak bergantung pada oksigen untuk bahan bakar. Sedangkan sistem energi aerobic untuk aktivitas intensitas rendah yang berlangsung dari dua menit hingga beberapa jam. Berbeda dengan dua sistem lainnya, sistem aerobik membutuhkan oksigen dan membutuhkan waktu lebih lama untuk kelebihan beban.

Dengan penggunaan perbedaan sistem energi yang berbeda maka akan mengakibatkan efek pada tekanan darah yang dimiliki oleh atlet. Intensitas latihan yang tinggi akan mengakibatkan penggunakan sistem energi yang cepat pakai. Dengan kebutuhan energi yang perlu cepat dapat digunakan, maka tubuh akan mempersiapkan kecukupan energi yang dibutuhkan. Percepatan penyediaan kebutuhan energi tersebut akan berdampak pada kinerja jantung dan peredaran 
darah. Selama olahraga jantung mengalami tekanan untuk memberikan suplai darah bagi tubuh. Semakin tinggi olahraga maka akan semakin tinggi pula tekanan jantung. Ketika atlet yang menggunakan sistem energi anaerobic maka tekanan pada jantung akan menjadi besar. Ketika atlet yang berada pada jenis cabang olahraga anerobik tentunya harus memiliki tekanan jantung yang normal. Ketika terjadi hal yang sebaliknya maka jantung akan memompakan darah dengan tekanan yang besar sehingga kinerja jatung akan semakin terbebani dan hal ini akan menggangu performa atlet. Perbedaan sistem energi dapat dilihat melalui perbedaan jenis cabang olahraga. Cabang olahraga akan mengindikasikan intensitas yang digunakan dalam cabang olahraga tersebut. Oleh karena itu, peneliti ingin membedakan perbedaan kecabangan olahraga dan tekanan darah yang dimiliki oleh atlet pra PON di Kalimantan Barat.

Kriteria tekanan darah normal untuk usia 13 tahun keatas adalah 120 hingga $129 \mathrm{mmHg}$ untuk tekanan darah systole dan kurang dari $80 \mathrm{mmHg}$ diastole, dan dikatakan hipertensi apabila tekanan darah lebih 130/80mmHg (Riley et al., 2018). Kategori pembagian tekanan darah berdasarkan American Hearth Association (AHA) adalah sebagai berikut:

Tabel 1. Pembagian kriteria Tekanan Darah berdasarkan AHA

\begin{tabular}{llll}
\hline $\begin{array}{l}\text { Kategori Tekanan } \\
\text { Darah }\end{array}$ & \multicolumn{1}{c}{ Sistole } & \multicolumn{1}{c}{ Diastole } \\
\hline Normal & $<120 \mathrm{mmHg}$ & Dan & $<80 \mathrm{mmHg}$ \\
Pre hipertensi & $120-129 \mathrm{mmHg}$ & Dan & $<80 \mathrm{mmHg}$ \\
Hipertensi stadium 1 & $130-139 \mathrm{mmHg}$ & Atau & $80-89 \mathrm{mmHg}$ \\
Hipertensi stadium 2 & $\geq 140 \mathrm{mmHg}$ & Atau & $\geq 90 \mathrm{mmHg}$ \\
\hline
\end{tabular}

(Lloyd-Jones et al., 2017)

\section{METODE}

Metode yang digunakan dalam penelitian ini adalah survei. Penelitian ini merupakan penelitian deskriptif, yaitu untuk mengetahui efek cabang olahraga terhadap tekanan darah atlet di Kalimantan Barat. Peneliti berusaha mengungkapkan fakta nyata yang terjadi di lapangan dan tidak bermaksud melakukan manipulasi data yang di peroleh. 
Populasi dalam penelitian ini adalah atlet berprestasi yang berada di bawah naungan KONI Kalimantan Barat. Sedangkan sampel dalam penelitian ini adalah atlet Kalimantan Barat yang berprestasi sesuai hasil porprov 2018 dan yang dipersiapkan untuk mengikuti event pra Pon dalam cabang olaahraga yang termasuk dalam kelompok anaerobic.

Teknik pengambilan data yang digunakan dalam penelitian ini adalah tes dan pengukuran Instrumen dalam penelitian ini adalah tensi meter. Data dikumpulkan dengan melakukan tes atau pengukuran terhadap tekanan darah atlet.

Analisis data merupakan kegiatan setelah data dari seluruh responden terkumpul. Kegiatan dalam analisis data adalah mengelompokan data berdasarkan variabel dan jenis responden, mentabulasi data berdasarkan variabel dari seluruh responden, menyajikan data dari tiap variabel yang di teliti.

\section{HASIL DAN PEMBAHASAN}

Dampak olahraga terhadap kesehatan sudah diketahui secara umum. Olahraga dapat dipergunakan dalam berbagai macam terapi seperti pada pasien penyakit kardiovaskuler (Villella \& Villella, 2014), sindrom metabolic (Lackland \& Voeks, 2014) dan bahkan juga digunakan untuk terapi pasien stroke (Moore et al., 2015). Penggunaan aktivitas olahraga ini karena dengan olahraga, maka akan memberikan efek lancarnya aliran darah yang dipompakan dari jantung ke seluruh tubuh. Olahraga akan membuat pembuluh darah mengalami vasodilatasi. Dengan demikian darah akan mengalir dengan cepat untuk dapat memberikan suplay oksigen dan nutrisi ke sel untuk dapat berperforma. Dengan demikian olahraga akan membuat jantung bekerja maksimal dan tekanan darah akan menjadi normal.

Olahraga dibagi menjadi dua, aerobic dan anaerobic. Perbedaan dengan sistem energi yang digunakan dan pola intensitas. Intensitas latihan pada olahraga anerobik tergolong pada intesitas yang tinggi. Intensitas latihan yang sedang hingga tinggi akan menurunkan tekanan darah (Zeigler et al., 2016;Boutcher \& Boutcher, 2017;Herrod et al., 2018). Oleh karena itu perlu dilakukan pengukuran terhadap atlet yang termasuk dalam cabang olahraga anaerobic dengan latihan intensitas tinggi terhadap tekanan darah atlet.

Penelitian ini dilakukan pada bulan Mei hingga September 2019. Dimana pelaksanaan pengambilan data dilakukan di gedung KONI Kalimantan Barat. 
Adapun jumlah populasi yang terkumpul sebanyak 374 orang atlet yang terdiri dari 26 cabang olahraga. sampel dalam penelitian ini adalah 10 cabang olahraga yang termasuk dalam kriteria anaerobic baik laktat maupun alaktat.

Tabel 2. Distribusi atlet setiap cabor

\begin{tabular}{llcc}
\hline \multirow{2}{*}{ No } & Cabang Olahraga & \multicolumn{2}{c}{ Jenis Kelamin } \\
\cline { 3 - 4 } & & Atlet \\
\hline 1 & Judo & 10 & 1 \\
2 & Karate & 10 & 8 \\
3 & Angkat Berat dan Besi & 13 & 6 \\
4 & Taekwondo & 7 & 3 \\
5 & Tarung Derajat & 13 & 12 \\
6 & Tinju & 24 & 8 \\
7 & Kempo & 3 & 5 \\
8 & Muaythai & 7 & 3 \\
9 & Pencak Silat & 16 & 11 \\
10 & Wushu & 12 & 2 \\
& $\quad$ Total keseluruhan & 115 & 59 \\
\hline
\end{tabular}

Jumlah sampel dalam penelitian ini sebanyak 174 orang atlet yang tersebar dalam 10 cabang olahraga, dengan komposisi jumlah atlet laki laki sebanyak 115 dan 59 atlet perempuan. Dari data diperoleh data rincian mengenai tekanan darah tiap atlet dapat dilihat pada tabel 3.

Tabel 3. Distribusi Karakteristik Tekanan Darah Atlet Tiap Cabang Olahraga

\begin{tabular}{|c|c|c|c|c|c|c|c|c|}
\hline \multirow[b]{2}{*}{ Cabang Olahraga } & \multirow{2}{*}{$\begin{array}{c}\text { Jenis } \\
\text { Kelami } \\
\text { n }\end{array}$} & \multicolumn{4}{|c|}{ Sistole } & \multicolumn{3}{|c|}{ Diastole } \\
\hline & & $\begin{array}{l}< \\
120\end{array}$ & $\begin{array}{l}120- \\
129\end{array}$ & $\begin{array}{l}130- \\
139\end{array}$ & $\begin{array}{l}> \\
140\end{array}$ & $<80$ & $80-89$ & $\begin{array}{c}>9 \\
0\end{array}$ \\
\hline \multirow{2}{*}{$\begin{array}{l}\text { Angkat Berat } \\
\text { dan Angkat Besi }\end{array}$} & $\mathrm{L}$ & 2 & 1 & 5 & 5 & 8 & 2 & 3 \\
\hline & $P$ & 2 & 0 & 2 & 2 & 3 & 1 & 2 \\
\hline \multirow{2}{*}{ Judo } & $\mathrm{L}$ & 0 & 1 & 6 & 3 & 9 & 1 & 0 \\
\hline & $\mathrm{P}$ & 0 & 0 & 0 & 1 & 0 & 1 & 0 \\
\hline \multirow{2}{*}{ Karate } & $\mathrm{L}$ & 2 & 1 & 1 & 6 & 1 & 6 & 3 \\
\hline & $\mathrm{P}$ & 5 & 2 & 0 & 1 & 6 & 1 & 1 \\
\hline \multirow{2}{*}{ Kempo } & $\mathrm{L}$ & 0 & 0 & 1 & 2 & 2 & 0 & 1 \\
\hline & $\mathrm{P}$ & 1 & 3 & 0 & 1 & 3 & 1 & 1 \\
\hline \multirow{2}{*}{ Muaythai } & $\mathrm{L}$ & 1 & 2 & 3 & 1 & 4 & 2 & 1 \\
\hline & $\mathrm{P}$ & 0 & 1 & 0 & 2 & 2 & 1 & 0 \\
\hline \multirow{2}{*}{ Pencak Silat } & $\mathrm{L}$ & 2 & 4 & 6 & 4 & 9 & 5 & 2 \\
\hline & $\mathrm{P}$ & 5 & 1 & 4 & 1 & 8 & 2 & 1 \\
\hline Taekwondo & $\mathrm{L}$ & 1 & 2 & 2 & 2 & 5 & 1 & 1 \\
\hline
\end{tabular}




\begin{tabular}{lcccccccc}
\hline \multirow{4}{*}{ Tarung Derajat } & $\mathrm{P}$ & 1 & 2 & 0 & 0 & 3 & 0 & 0 \\
\multirow{3}{*}{ Tinju } & $\mathrm{L}$ & 3 & 1 & 7 & 2 & 12 & 1 & 0 \\
\multirow{3}{*}{ Wushu } & $\mathrm{P}$ & 6 & 4 & 2 & 0 & 11 & 1 & 0 \\
& $\mathrm{~L}$ & 7 & 6 & 6 & 5 & 17 & 6 & 1 \\
& $\mathrm{P}$ & 4 & 1 & 2 & 1 & 5 & 1 & 2 \\
& $\mathrm{~L}$ & 3 & 3 & 4 & 2 & 10 & 1 & 1 \\
& $\mathrm{P}$ & 1 & 0 & 0 & 1 & 1 & 0 & 1 \\
\hline
\end{tabular}

Semua atlet judo memiliki kriteria pre hipertensi dan hipertensi. Sumbangan penderita hipertensi baik itu dari stadium 1 maupun stadium 2 terbesar adalah dari cabang olahraga angkat berat dan angkat besi. Atlet yang termasuk dalam kriteria normal tekanan darahnya hanya berjumlah 46 atlet dari 174 atlet yang menjadi sampel apabila ditinjau dari tekanan darah systole sedangkan 128 atlet termasuk dalam kriteria pre hipertensi dan hipertensi, namun jika ditinjau dari tekanan darah diastole maka yang termasuk dalam kriteria normal sejumlah 119 atlet. Ditinjau dari tekanan darah systole terdapat 35 atlet termasuk dalam kriteria pre hipertensi, 51 atlet termasuk dalam kriteria hipertensi stadium 1 dan 42 atlet termasuk dalam hipertensi stadium 2. Sedangkan apabila ditinjau dari tekanan darah diastole maka terdapat 34 atlet termasuk kriteria hipertensi stadium 1 dan 21 atlet termasuk dalam kriteria hipertensi stadium 2. Sedangkan atlet yang termasuk memiliki kriteria tekanan darah normal berdasarkan tekanan darah systole terdapat 46 atlet, dan 119 atlet berdasarkan tekanan darah diastole. Lebih lengkap bisa dilihat pada gambar 1 .

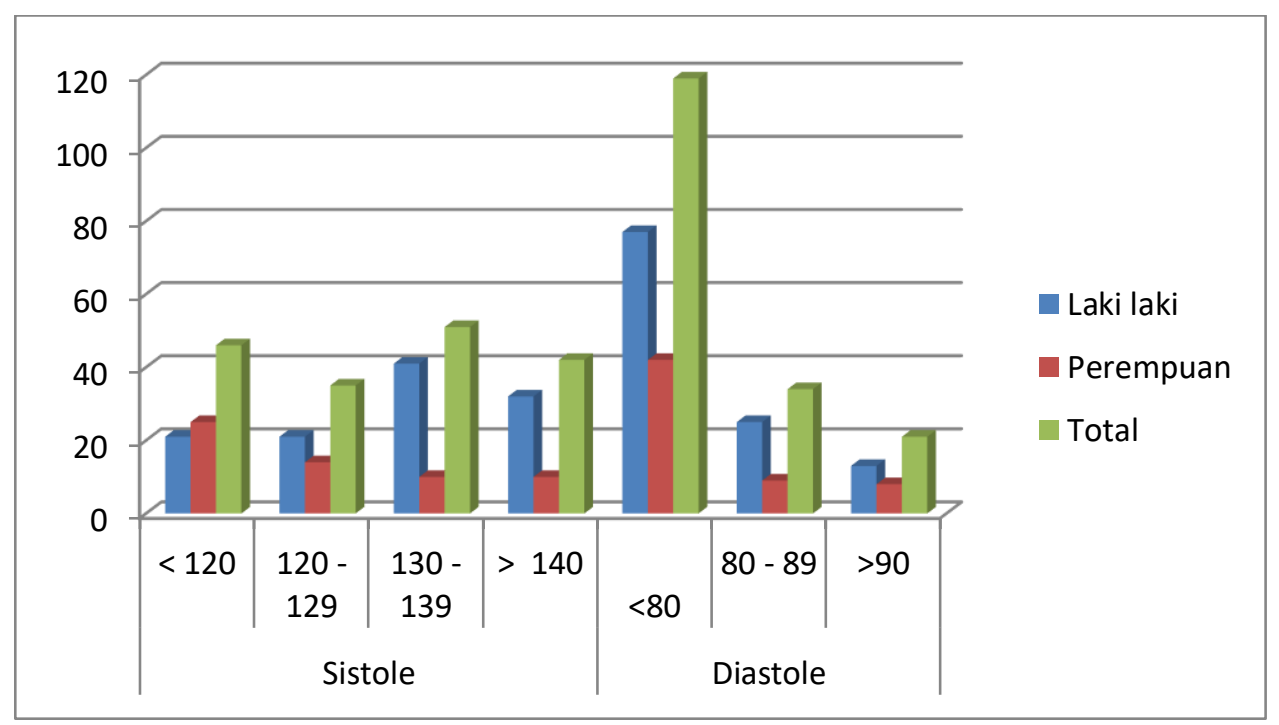

Gambar 1. Grafik Penyebaran Tekanan Darah Berdasarkan Jenis Kelamin Atlet 
Memiliki tekanan darah yang termasuk dalam kriteria normal adalah modal awal atlet untuk dapat berperforma dengan baik. Berdasarkan data yang ada atlet di Kalimantan Barat termasuk dalam kriteria pre hipertensi dan hipertensi stadium 1 dan bahkan stadium 2. Seorang atlet termasuk dalam kriteria individu yang aktif, yang sudah menjadi seharusnya bahwa atlet-atlet terbaik Kalimantan Barat tersebut memiliki kriteria tekanan darah yang normal. Karena individu yang aktif secara fisik akan memiliki tekanan darah yang rendah, tingkat sensitivitas terhadap insulin yang tinggi, dan profil plasma lipoprotein yang baik (Nystoriak \& Bhatnagar, 2018b). Meskipun peningkatan tekanan darah sistolik memiliki efek yang lebih besar pada hasil, baik hipertensi sistolik dan diastolik secara independen mempengaruhi risiko kejadian kardiovaskular yang merugikan, terlepas dari definisi hipertensi $(\geq 140 / 90 \mathrm{~mm} \mathrm{Hg}$ atau $\geq 130 / 80 \mathrm{~mm} \mathrm{Hg}$ ) (Flint et al., 2019)

Perbedaan karakteristik cabang olahraga akan membuat latihan yang berbeda. Hal ini kemungkinan besar berdampak pada atlet anaerobic yang menjadi sampel dalam penelitian ini, terutama pada cabang olahraga angkat berat dan angkat besi.

Latihan aerobic, latihan resisten dinamik, atau kombinasi aerobic dan latihan resisten dinamik selama tiga bulan dengan intervensi pada gaya hidup akan menurunkan tekanan darah $5 \mathrm{mmHg}$ pada tekanan darah systole dan $3 \mathrm{mmHg}$ pada tekanan diastole (Herrod et al., 2018b). Latihan olah raga selama empat bulan pada pasien prehipertensi dan hipertensi ringan tidak hanya menurunkan tingkat tekanan darah (Zheng et al., 2016), melalui program latihan akan meningkatkan $\mathrm{VO}_{2}$ maks, power, ambang batas anaerobic, dan pemulihanan detak jantung lebih cepat, selain itu tekanan darah systole dan diastole akan menurun secara signifikan. Latihan resistensi intensitas rendah dengan mengikat alirah darah (BFR) dapat menghasilkan: (i) nilai hemodinamik yang sama selama latihan; (ii) peringkat tenaga kerja yang dirasakan lebih rendah; (iii) menurunkan laktat darah; (iv) kebutuhan hemodinamik yang lebih tinggi selama interval istirahat (Pinto et al., 2018).

Tekanan darah tinggi atau hipertensi seharusnya dapat ditanggulangi oleh olahraga yang teratur dan terukur. Beberapa penelitian telah dilakukan untuk 
menanggulangi hipertensi. Latihan aerobic dalam jangka pendek maupun jangka panjang akan menurunkan tekanan darah (Bruneau et al., 2016). Penurunan tekanan darah lebih besar terjadi pada partisipan laki-laki yang tidak mengkonsumsi obat anti hipertensi, aktif secara fisik dan joging (Carpio-Rivera et al., 2016). Dari dua penelitian tersebut mengindikasikan bahwa latihan aerobic ringan akan menurunkan tekanan darah.

Hal tersebut terbantahkan oleh penelitian selanjutnya. Latihan aerobik intensitas dibawah 70\% tidak menghasilkan efek penurunan tekanan darah. Namun, latihan aerobik dan anaerobik intermiten yang dilakukan pada intensitas $>70 \%$ akan mengurangi tekanan darah pada pasien yang mengalami hipertensi (Boutcher \& Boutcher, 2017). Hal ini sejalan dengan penelitian mengenai latihan HIIT dapat mengakibatkan tekanan systole, diastole dan detak jantung. Latihan HIIT dan MIT sama-sama menurunkan level tekanan darah, namun terihat lebih banyak pada program latihan HIIT (Jakovljevic et al., 2019).

Intensitas latihan yang tinggi melebihi $85 \%$ selalu dilakukan oleh atlet terutama oleh atlet angkat berat dan angkat besi. Namun pada kenyataannya pada cabang olahraga tersebut atletnya justru mengalami hipertensi baik itu stadium 1 maupun stadium 2. Hal ini sejalan dengan penelitian mengenai dampak peningkatan tekanan darah terhadap kapasitas olahraga pada atlet elit bahwa pada atlet yang mengalami prehipertensi dan hipertensi mempunyai kapasitas $\mathrm{VO}_{2}$ maks, ambang batas anaerobic, dan detak jantung yang rendah (Mazic et al., 2015). Terutama pada cabang olahraga penyumbang hipertensi, memiliki kapasitas aerobic yang sangat mengkhawatirkan.

Sepuluh cabang olahraga yang tergolong pada kelompok anaerobic tentu saja sering melakukan latihan yang tergolong dalam kriteria intensitas tinggi. Dalam penelitian ini tergambarkan bahwa atlet meskipun melakukan latihan denegan intensitas tinggi namun masih memiliki tekanan darah yang tinggi. Hal tersebut sangat berbahaya bagi kesehatan atlet. Tingginya tekanan darah terutama pada Meskipun kemungkinan penyakit kardiovaskuler tidak terjadi, namun keadaan tekanan darah tinggi atau ang dikenal dengan hipertensi dapat mengganggu pereforma atlet. Terutama pada kapasitas $\mathrm{VO}_{2}$ maks atlet. 
Perlu adanya penangganan lebih lanjut agar performa atlet tidak terganggu oleh adanya keadaan hipertensi yang diderita oleh atlet. Salah satu langkah yang harus ditempuh adalah adanya pengaturan makanan untuk atlet. Beberapa penelitian menunjukkan bahwa serat makanan juga dapat meningkatkan glikemia, resistensi insulin, dan penurunan berat badan. Asupan serat dapat menurunkan tekanan darah arteri pada tikus hipertensi, namun serat tertentu dapat meningkatkan tekanan darah arteri bila diberikan pada subjek hipertensi dan prahipertensi (Aleixandre \& Miguel, 2016). Selain itu bawang merupakan supplement ampuh untuk menurunkan tekanan darah terlebih pada penderita hipertensi (Wang et al., 2015).

Pengaturan makanan yang boleh dan tidak boleh dikonsumsi atlet selama training centre memang harus dilakukan, sehingga keadaan hipertensi yang diderita bisa dihilangkan. Bukan hanya sekedar jenis makanan saja, tetapi bahan yang terkandung di dalamnya termasuk gula dan garam. Garam merupakan faktor utama terjadinya peningkatan tekanan darah, demikian juga dengan asupan tinggi gula akan meningkatkan kejadian obesitas yang pada gilirannya akan meningkatkan tekanan darah (He \& MacGregor, 2015).

\section{SIMPULAN}

Berdasarkan penelitian atlet yang diberangkatkan mengikuti Pra PON 2019 pada cabang olahraga anaerobik sebagian besar mengalami prehipertensi dan hipertensi baik stadium 1 maupun stadium 2. Atlet yang termasuk dalam kriteria normal berjumlah 46 atlet dari 174 atlet yang menjadi sampel apabila ditinjau dari tekanan darah systole, namun jika ditinjau dari tekanan darah diastole maka yang termasuk dalam kriteria normal sejumlah 119 atlet. Namun indikator utama hiepertensi adalah besarnya tekanan darah systole. Dalam hal ini terdapat 128 atlet cabang olahraga anaerobic tergolong dalam kriteria hipertensi. Kesimpulan yang dapat diambil dari penelitian ini adalah bahwa latihan intensitas tinggi yang dilakukan oleh atlet anaerobic tidak berhasil menurunkan tekanan darah atlet. Hal ini sangat berbahaya bagi kesehatan atlet, dimana atlet cabang olahraga dengan penggunaan sistem energi anaerobic memerlukan performa jantung yang maksimal. Perlu adanya upaya untuk membuat tekanan darah menjadi lebih 
mendekati normal dengan penerapan intensitas latihan yang tepat dan juga pengaturan jenis dan jumlah makanan pada atlet.

\section{DAFTAR RUJUKAN}

Aleixandre, A., \& Miguel, M. (2016). Dietary fiber and blood pressure control. Food and Function, 7(4), 1864-1871. https://doi.org/10.1039/c5fo00950b

Boutcher, Y. N., \& Boutcher, S. H. (2017). Exercise intensity and hypertension: What's new? Journal of Human Hypertension, 31(3), 157-164. https://doi.org/10.1038/jhh.2016.62

Bruneau, M. L., Johnson, B. T., Huedo-Medina, T. B., Larson, K. A., Ash, G. I., \& Pescatello, L. S. (2016). The blood pressure response to acute and chronic aerobic exercise: A meta-analysis of candidate gene association studies. Journal of Science and Medicine in Sport, 19(5), 424-431. https://doi.org/10.1016/j.jsams.2015.05.009

Carpio-Rivera, E., Moncada-Jiménez, J., Salazar-Rojas, W., \& Solera-Herrera, A. (2016). Acute effects of exercise on blood pressure: A meta-analytic investigation. Arquivos Brasileiros de Cardiologia, 106(5), 422-433. https://doi.org/10.5935/abc.20160064

Caselli, S., Serdoz, A., Mango, F., Lemme, E., Vaquer Seguì, A., Milan, A., ... Pelliccia, A. (2019). High blood pressure response to exercise predicts future development of hypertension in young athletes. European Heart Journal, 40(1), 62-68. https://doi.org/10.1093/eurheartj/ehy810

Flint, A. C., Conell, C., Ren, X., Banki, N. M., Chan, S. L., Rao, V. A., ... Bhatt, D. L. (2019). Effect of systolic and diastolic blood pressure on cardiovascular outcomes. New England Journal of Medicine, 381, 243-251. https://doi.org/10.1056/NEJMoa1803180

He, F. J., \& MacGregor, G. A. (2015). Salt and sugar: their effects on blood pressure. Pflugers Archiv European Journal of Physiology, 467, 577-58. https://doi.org/10.1007/s00424-014-1677-x

Herrod, P. J. J., Doleman, B., Blackwell, J. E. M., O’Boyle, F., Williams, J. P., Lund, J. N., \& Phillips, B. E. (2018). Exercise and other nonpharmacological strategies to reduce blood pressure in older adults: a systematic review and meta-analysis. Journal of the American Society of Hypertension, 12(4), 248267. https://doi.org/10.1016/j.jash.2018.01.008

Jakovljevic, B., Nikolic Turnic, T., Jeremic, N., Jeremic, J., Bradic, J., Ravic, M., ... Zivkovic, V. (2019). The impact of aerobic and anaerobic training regimes on blood pressure in normotensive and hypertensive rats: focus on redox changes. Molecular and Cellular Biochemistry, 454(1-2), 111-121. https://doi.org/10.1007/s11010-018-3457-y 
Lackland, D. T., \& Voeks, J. H. (2014). Metabolic Syndrome and Hypertension: Regular Exercise as Part of Lifestyle Management. Current Hypertension Reports, 16(11), 492. https://doi.org/10.1007/s11906-014-0492-2

Leddy, J. J., Haider, M. N., Ellis, M., \& Willer, B. S. (2018). Exercise is Medicine concussion. Current Sports Medicine Reports, 17(8), 262-270. https://doi.org/10.1249/JSR.0000000000000505

Lloyd-Jones, D. M., Morris, P. B., Ballantyne, C. M., Birtcher, K. K., Daly, D. D., DePalma, S. M., ... Smith, S. C. (2017). 2017 Focused Update of the 2016 ACC Expert Consensus Decision Pathway on the Role of Non-Statin Therapies for LDL-Cholesterol Lowering in the Management of Atherosclerotic Cardiovascular Disease Risk: A Report of the American College of Cardiology Task Fo. Journal of the American College of Cardiology, 70(14), 1785-1822. https://doi.org/10.1016/j.jacc.2017.07.745

Mazic, S., Suzic Lazic, J., Dekleva, M., Antic, M., Soldatovic, I., Djelic, M., ... Suzic, S. (2015). The impact of elevated blood pressure on exercise capacity in elite athletes. International Journal of Cardiology, 1(180), 170-177. https://doi.org/10.1016/j.ijcard.2014.11.125

Moore, S. A., Hallsworth, K., Jakovljevic, D. G., Blamire, A. M., He, J., Ford, G. A., Rochester, L., \& Trenell, M. I. (2015). Effects of Community Exercise Therapy on Metabolic, Brain, Physical, and Cognitive Function Following Stroke: A Randomized Controlled Pilot Trial. Neurorehabilitation and Neural Repair, 29(7), 623-635. https://doi.org/10.1177/1545968314562116

Nystoriak, M. A., \& Bhatnagar, A. (2018). Cardiovascular Effects and Benefits of Exercise. Frontiers in Cardiovascular Medicine, 5, 135. https://doi.org/10.3389/fcvm.2018.00135

Pinto, R. R., Karabulut, M., Poton, R., \& Polito, M. D. (2018). Acute resistance exercise with blood flow restriction in elderly hypertensive women: Haemodynamic, rating of perceived exertion and blood lactate. Clinical Physiology and Functional Imaging, 38(1), 17-24. https://doi.org/10.1111/cpf.12376

Qiu, Z., Zheng, K., Zhang, H., Feng, J., Wang, L., \& Zhou, H. (2017). Physical Exercise and Patients with Chronic Renal Failure: A Meta-Analysis. BioMed Research International, 2017(7191826). https://doi.org/10.1155/2017/7191826

Riley, M., Hernandez, A. K., \& Kuznia, A. L. H. blood pressure in children and adolescents. (2018). High blood pressure in children and adolescents. American Family Physician, 98(8), 486-494.

Wang, H. P., Yang, J., Qin, L. Q., \& Yang, X. J. (2015). Effect of Garlic on Blood Pressure: A Meta-Analysis. Journal of Clinical Hypertension, 17(3), 223231. https://doi.org/10.1111/jch.12473

Way, K. L., Sultana, R. N., Sabag, A., Baker, M. K., \& Johnson, N. A. (2019). 
The effect of high Intensity interval training versus moderate intensity continuous training on arterial stiffness and $24 \mathrm{~h}$ blood pressure responses: A systematic review and meta-analysis. Journal of Science and Medicine in Sport, 22(4). https://doi.org/10.1016/j.jsams.2018.09.228

Zeigler, Z. S., Mullane, S. L., Crespo, N. C., Buman, M. P., \& Gaesser, G. A. (2016). Effects of standing and light-intensity activity on ambulatory blood pressure. Medicine and Science in Sports and Exercise, 48(2), 175-181. https://doi.org/10.1249/MSS.0000000000000754

Zheng, H., Xie, N., Xu, H., Huang, J., Xie, X., \& Luo, M. (2016). Effects of 4 month exercise on left ventricular remodeling and autonomic nervous system in hypertensive patients. Panminerva Medica, 58(1), 1-7. 